\title{
Causes of Cost Overrun in Federal Road Projects of Ethiopia in Case of Southern District
}

\author{
Ashebir Shiferaw Belachew ${ }^{1}$, Wubishet Jekale Mengesha ${ }^{2}$, Murad Mohammed ${ }^{1}$ \\ ${ }^{1}$ School of Civil and Environmental Engineering, Jimma University Institute of Technology, Jimma, Ethiopia \\ ${ }^{2}$ School of Civil and Environmental Engineering, Addis Ababa University Institute of Technology, Addis Ababa, Ethiopia
}

Email address:

ashebirshif@gmail.com (A. S. Belachew), wubishetj@gmail.com (W. J. Mengesha), muradjima@gmail.com (M. Mohammed)

To cite this article:

Ashebir Shiferaw Belachew, Wubishet Jekale Mengesha, Murad Mohammed. Causes of Cost Overrun in Federal Road Projects of Ethiopia in Case of Southern District. American Journal of Civil Engineering. Vol. 5, No. 1, 2017, pp. 27-40. doi: 10.11648/j.ajce.20170501.15

Received: October 11, 2016; Accepted: October 22, 2016; Published: January 5, 2017

\begin{abstract}
One of the problems has been broadly published in different literature related to construction project management is project cost overrun. To fill this gap, the study on causes of cost overrun was conducted. It was conducted on 18 road construction projects with eight case studies which is found under the southern district of Ethiopian Road Authority. Based on a comprehensive literature review and archives, 40 factors linked to project cost performance were acknowledged for analysis. Based on the percentage of maximum score rank of 40 identified factors, six top rated factors were identified. These are material price fluctuation, cost underestimation, delay in supply of raw materials, inadequate review of contract documents, lack of coordination at the design phase and lack of cost planning during pre- and post- contract stage have the highest impacts on the performance of project costs from the client's, consultants' and contractors' perspective. This study has been done through survey and case study to generate raw data. The questionnaires were distributed to 54 practitioners to evaluate the significance of the factors that causes the project cost overrun. In addition, case studies were used to find the magnitude of cost overrun on selected projects by an in-depth analysis of an archive of each project. The magnitude of cost overrun among selected project extended from $4.16 \%$ to $83.2 \%$. While the average magnitude of cost overrun was nearly $21.52 \%$, this is a significant amount when it compared with the number of projects.
\end{abstract}

Keywords: Construction Phase, Project cost Estimation, Project Cost Extent, Project Cost Management, Project Cost Overrun, Project Scope

\section{Introduction}

The construction industry is multipart in nature because it involves different technology, a reasonable size of the projects; a high level of organizational complexity and different parties (client, contractor, consultant, Supplier, Bank, Insurance, permitting agency and public) [1]. It has a major role in the economic developments of one society [2].

Since it opens an opportunity for the large employments; create a market for construction inputs providers and its services and the services delivered are an input for other sec-tors. Due to its enormous investment, it's considered as an economic uplifting of a country [3]. That is why developing countries also invest in infrastructure de-velopment to increase their infrastructure status that is used to compete in the globalized world [4].
The development of infrastructure has positive significant effect for developed and developing society, predominantly road projects in the aspects of creating the direct and indirect career opportunity, improve the standards of the country internationally as well as locally [5]. This positive significance depends on the achievements of the goal of the project, which is accomplishing the project within the available environment by putting together all the resources in bounded time, estimated project cost and specified quality [3].

However, due to different factors the project work is not completed within bounded time, estimated costs and re-quired quality. Under this study the driving force was the questions of "why the project didn't achieve its goal within pre estimated cost? What are the main reasons behind this?"

Hence, this study mainly focuses on the potential prob-lem behind the road project cost overrun through scientific approach. 
During the implementation of the infrastructure, particu-larly in road projects, one of the main problem observed for the construction parties is the problem of the cost overrun [6]. The project cost overrun is considered as a challenge due to the reasons of leading to wasteful allocation of resources, leading to delays and further cost overruns; it destabilizes policy, planning, implementation, and operations of projects; lastly for the bigger project the problem is bigger which destabilize the finances of a whole country [7].

For instance, the Boston's Central Artery/Tunnel Project faces the technical and logistic challenges that increase the project costs from $\$ 2.5$ Billion to $\$ 14.63$ billion [1], nearly the project cost overrun is $485 \%$. The study of [9] and [10] show that the problem of project cost overrun is also a problem in de-veloping country like Ethiopia. It was significant in the Ethi-opian road project - the study conducted by [2] Shows that $80 \%$ of the projects were experiencing the cost overrun. This implies that eight out of ten projects were exposed with the problem of project cost overrun.

\section{Literature Review}

\subsection{Construction Projects in Ethiopia}

The construction sector is one of the most important con-tributors for the political, economic, social and technological development of one country [2]. Existing facts show that about $50 \%$ of the Federal capital budget of Ethiopia is routed to the development of physical infrastruc-ture, from this nearly $33 \%$ were for the road projects [12]. Besides, the involvement of the private sector as the partners in the capital investment, increased capital investment in the field, as well as, promote more advanced technologies and materials.

This sector is significantly increase both in volume and density of work seen in construction of Ethiopia. A number of study in the public sector show that more than $80 \%$ of the construction projects are delayed, run over budget and/or lack the management [10]. Furthermore, the indus-try still largely relays upon labor intensive on site activities, which lack plant manufactured and site assembled con-struction. The weakening quality of construction works is also clearly superficial. While the understanding of the con-struction projects [3]indicate that, the con-struction project and management is high-value, time bound and predetermined performance under the management of the time and progress, cost and cash flow as well as quality and performance within the available organizational re-sources through planning and scheduling that resources.

Mostly, Ethiopian road projects are financed by the Gov-ernment and it is sensitive to the unpredictable costs [13]. Whereas significant amount of capital is being invested in to infrastructure development, the infrastructure of the country is still considered to be very poor, when it compared with the standards of the Sub-Saharan countries [13].

\subsection{Cost Overrun; Extent and Causes}

\subsubsection{Extent of Cost Overrun}

The construction project cost estimation helps either public or private organ to plan the self-financial capacity. But due to different conditional or unconditional situations the pro-ject may not complete within budgeted costs. For instance, the British Parliamentary Committee criticized the escalat-ing costs of the 2012 London Olympic infrastructure costs. As the Olympics Minister said infrastructure cost had risen by $\$ 1.8$ billion from $\$ 4.7$ billion number mentioned in the bid. Also the Boston's Central Artery/Tunnel Project faces the technical and logistic challenges that increase the project costs from $\$ 2.5$ Billion to $\$ 14.63$ billion [8].

The amount of cost overrun is not the problem of specific areas and from country to country is variable, either in de-veloping or developed countries. In Palestine $76 \%$ of the pro-jects are averagely underestimated. Which pushing the country to the unplanned financial crises [14]. This percentage also related with $77 \%$ of the highway projects of US which have $50 \%$ of cost overrun, cited by [15]. It also linked to the investigated magnitude of cost overrun in Dutch infrastructure projects in their series of studies. The road projects experience $18.6 \%$ of the total costs [16]. The project cost over-run in developing countries are one of the problem seen mostly in different public projects. Public Private Partner-ship (PPP) infrastructure projects in India nearly $69 \%$ of the project experience's cost overrun which cost around $\$ 76.49$ million. The academic study conducted in Ethiopia on 24 projects by [11] Shows $80 \%$ of the projects are experiencing the cost overrun.

Generally, the [17] shows the rate of cost overrun throughout the world of infrastructure is $28 \%$. The study concludes cost overrun of the construction projects exists across 20 nations and five continents; it is a global phenomenon and nine of 10 transportation infrastructure projects fall under cost escalation $(n=258)$. Roads projects, average cost escalation was $20 \%$, Cost escalation appears to be more pronounced in developing nations than in devel-oped countries.

The degree of achievements in any activity expresses the performance of a project. The performance of the cost of the projects has an influence on the schedule or duration of the projects as well as on the quality of each activity [18]. For the degree of achievements of the budgeted cost, each responsibility center accountable [3]. There could be many reasons behind the problems of costs. To control the project cost, it needs an investigation to identi-fy the inherent variables that could be the source of the prob-lems.

\subsubsection{Causes of Cost Overrun}

In different countries the road projects are owned State and it includes different stakeholders. However, in different road construction projects what observed was all team of the projects were not participating actively at the beginning stages [19]. This leads the projects to the possibility of un-expected cost. Some of the reputable factors that cause the project's cost overrun according to different researchers are tabulated as follow. 
Table 1. Factors cause cost overrun.

\begin{tabular}{ll}
\hline Factors & Literature \\
\hline $\begin{array}{l}\text { Scope creep and inadequate review } \\
\text { of Contract Document }\end{array}$ & {$[20],[21]$} \\
Poor site management & {$[22],[23],[24],[22],[25],[26],[27]$} \\
$\begin{array}{l}\text { Contingency and project size } \\
\text { Inaccuracy of cost Estimation and }\end{array}$ & {$[28],[29],[30]$} \\
Escalation & {$[14],[31],[17],[32],[10]$} \\
$\begin{array}{l}\text { Communication } \\
\text { Internal and External Factors }\end{array}$ & {$[33],[34],[35],[36],[37],[38],[39]$} \\
\hline
\end{tabular}

\subsection{Construction Phases and Causes of Cost Overrun}

The core components of a project include a clear begin-ning and end, unique outcomes, a specific timeline, a one-time budget, and a multidiscipline team [44]. The projects have defined phases between the project kickoff and project closeout. A phase represents a grouping of similar activities that has a very roughly defined beginning and end. Phase are also typically sequential, where the prior phase is basically complete before the beginning of the next phase. Phases do not have clear-cut end dates and any activities in an early phase of the project will continue in the later phas-es. This is in contrast to project beginning and ending dates and milestone dates [45].

Construction projects need an art instead of the science. And in investigating all the steps follow at each construction stage of construction from the owner's planning and budget-ing, through the design and contractor selection stage, and physical construction stage of the projects is completed and turned over to the owner for use is combinations of an art of coordination and management applied at each step of the construction project schedule and budget. It includes the ability of bringing team works together to the common vi-sion and individual accomplishments to the organizational objectives. This ability of coordinating among all the players involved occurs throughout the project phases of the projects to attain the successful delivery of the project accomplish-ment. Even if there is no clear boundary of construction phases ordinarily the phases of the projects broken into three main sections: Pre-construction phase, construction phases and the post-construction phases [46], [47], [3], [48]. Under these stages there are different activities and if they are not proper-ly managed, they are a reason for the cost overrun.

\subsubsection{Pre-Construction Phase}

The research conducted in India by the [19] show there is direct relationships between the problems of cost over-run and phases of construction projects. Different factors cause the problems either at pre-execution or at the execution phase of the projects. Scope creep and inadequate Detailed Project Re-port (DPR) is primary factors (scope creep, inadequate of DPR which is original estimate and budgeting of the projects, acquisi-tion of the land at the market price, high cost of the Environmen-tal safeguard, poor selection of the consultant, lack of strong R \& R polices, non-flexible country plan) are the main aggregated factors which initiate the cost overruns at the pre-construction phase of the projects.

\subsubsection{Construction Phase}

Construction is the mobilization and utilization of capital and specialized personnel, materials, and equipment to assemble materials and equipment on a specific site in accordance with drawings, specifications, and contract documents prepared to serve the purposes of a client [49]. At this phase usually different activities performed for the successes of the construction projects.

Different studies [19] and [50] identifies the factors for the occurrence of cost overrun at the construction and closing phase. Material price escalation beyond projection, escalation in labor costs/ ineffective utiliza-tion of the labor, design change/ iteration, inadequate availability of the skilled resources, weak contract administration and claim management, contractual dispute due to poor framing of the contract documents and wrong/ poor selection of technology or equipment are causes of project cost overrun at construction phase of the projects.

\section{Research Methodology}

The research method can be defined as the way in which the research objectives can be examined [51]. Through the inductive approach, plans are made for data collection, after which the data were analyzed to see if any patterns emerge that suggest relationships between variables.

For this study the main data variables are related to the actual cost and estimated cost, because these variables express the cost overrun. Cost overrun is measured as the actual cost minus the estimated cost. Actual cost, according to [16] defined as a real record of the financial expenditure costs at the time of project completion. Whereas the Estimated cost defined as budgeted or calculated construction cost at the time of formal decision to construct. In order to identify the variable related to the above concepts and relate them together, there is a need of systematically solving the research problem, which is research approach [52].

This study conducted through survey and case study to generate raw data. Surveys were used to gather data from a relatively large number of respondents within a limited time frame. The survey through questionnaire conducted on projects that have been experienced cost overrun. The aim of the questionnaire was to identify the common factors causes cost overrun.

Case studies were used to support the argument by an in-depth analysis of an archive of a particular project. which documents required by law or by constructing contracts, including monthly reports, construction schedules, project payment and contracting document of the construction projects.

This study primarily used two separate methods to analyze the collected data to identify the top rated factors among all three parties that affect the project cost performance. A descriptive approach to direct interpretation of the case study and survey results to identify the magnitudes and the top rated influencing factors based on content analysis and percentage of maximum score respectively [53] and [51]. 
In addition, the spearman correlation coefficient analysis was made to explore the association degree of the survey respondent among the three parties - client, consultants and contractors.

Spearman's formula is given as:

$$
r h o=1-\frac{6 \sum d_{i}^{2}}{N\left(N^{2}-1\right)}
$$

\section{Spearman's formula}

Where rho $=\rho=$ Spearman coefficient

$\mathrm{di}=$ the difference between ranks

$\mathrm{N}=$ number of subjects or pairs of ranks

The correlation coefficient $\rho$ ranges from -1.0 to +1.0 . The closer $\rho$ is to +1 or -1 , the more closely the two variables are related. The value of $\rho$ close to 1 implies there is strong positive linear relationship between the two variables while the value of $\rho$ close to -1 shows a strong negative linear relationship between the two variables. If the correlation coefficient value lies between \pm 0.5 and \pm 1 , it is said to have a high degree of correlation. For correlation coefficient value between \pm 0.3 and \pm 0.5 , the degree of correlation is moderate. Low degree of correlation occurs when the correlation coefficient lies between \pm 0.1 and \pm 0.3 . Meanwhile, zero coefficient value represents no correlation at all [43].

\section{Result and Analysis}

\subsection{Analyzing Case Study}

There are some requirements in the selection of project archive and interviewees in case studies. For this study, the case study protocol and data base was developed on two different categories of projects, which is case study A and case study B.

The features of the project under case study A and case study B were collected depend on their completion status. Specifically, project under case study A were substantially completed and Case Study B were ongoing or projects left with minor finishing works (percentage of completion reaches more than $94 \%$ ).

Cost related information was problematic to get. Hence, the information was collected based on the financial reports including monthly reports, construction schedules, project payment and contracting document of the construction of projects. Besed on this six substantially completed and two ongoing projects selected for case A and B.

\subsubsection{Case A: Substantially Completed Project}

Facts: total cost disbursements 2.23 ETB billion;

All projects were experienced cost overrun;

Average Extension of time was more than 427 calendar days

The projects were executed by own force, local contractors and foreign contractors. In Table 2 the status for each project were presented.

The physical progress of the project was greatly behind its original schedule and total delayed by around 16 months. The financial progress of the project also above expected percentages - averagely the amount of project cost overrun was $24.69 \%$. Both the cost and time overrun shows all the projects were lacking the managements.

Table 2. Project status under case A.

\begin{tabular}{|c|c|c|c|c|c|c|}
\hline Project & Wadra & Wazeka & Key Afer & Endeto & Sodo & Chida \\
\hline Estimated project cost (in Million) & 617.7 & 312.2 & 114.7 & 390.3 & 91 & 209.1 \\
\hline Actual project cost (in Million) & 675.9 & 325.2 & 125.4 & 715.2 & 95.5 & 264.1 \\
\hline Amount of cost overrun (in Million) & 58.2 & 13 & 10.7 & 324.9 & 4.5 & 55.0 \\
\hline Percentage of cost overrun & 9.42 & 4.16 & 9.33 & 83.24 & 4.95 & 37.07 \\
\hline
\end{tabular}

What were Understoods during the assessment of this case, variation order was dominant problem. Such as the variation due to the failed pipe structure, variation due to additional works and variation due to provision of retaining wall were dominant problems. In addition to this design change, right of way problem, adverse weather condition, Inadequate and delayed resources (labor and construction equipment), poor management and workmanship, and market price escalation were the problem that cause the project cost overrun under this case.

Furthermore, unclear claim was also raised on some projects. Contractor's main issues were claim for extention of time (EOT) due to Employer's delaying events rise to additional days over and above the original and revised completion project date. Moreover, the increase in Earth work quantities and scarcity of cement were Employer's delaying events. The frequent breakdown of machineries, and inadequate labor and equipment deployment were among the claim raised.

\subsubsection{Case B: Ongoing Project}

Facts: the project under this case were left with minor works. At this status both the projects have a cost overrun and price adjustment to date.

There was a claim due to unforeseen ground and subsurface condition, and abnormality of the natural soil. The project under case B have experienced the cost overrun, nearly $12 \%$ rate. Overview of the project cost status of the project under this case were presented in Table 3.

Table 3. Project cost status under case study B.

\begin{tabular}{lll}
\hline Project & Yabelo - Lot I & Yabelo - Lot II \\
\hline Estimated project cost (in Million) & 176.00 & 207.00 \\
Actual project cost (in Million) & 195.20 & 234.10 \\
Amount of cost overrun (in Million) & 19.15 & 27.06 \\
Percentage of cost overrun & 10.91 & 13.09 \\
\hline
\end{tabular}

The project under this case have a claim related above mentioned factors. For instance, nearly seven million ETB 
potential costs were asked for unforeseen ground, as well as around 8.3 million of ETB were claimed for the abnormality of the natural soil. However, until the data collected for this study have been made the claim were not finalized.

From the assessment, the variation order and delay were common in both projects. Variation related to revised and additional cross drainage structures, refill for vertical profile revision due to occurrence of hard rock and provision of cattle crossing in different locations.

Although a delay of construction Engineer's camp, lack of fixing of construction machineries, delay of work due to lack of motivation of worker and skilled labors, lags in the erection of screening plant and allocation of construction machineries where the problem with the project under case B.

\subsection{Magnitude of Cost Overrun}

A comparative analysis of cost overruns between different projects or districts are interesting trends, it is useful for comparison of the magnitude of costs among the projects. As the different study describes [11] and [54] majority of ERA projects experience cost overruns and the cost overrun amounts vary among the projects. The extents of cost overrun were dependent on the volume of contract and the range was varying between the projects. The magnitude of cot overrun of selected project under both cases are shown on figure 1

The percentage rate of cost overrun among these project extended from $4.16 \%$ to $83.2 \%$. While the average percentage of cost overrun was nearly $21.52 \%$, this costs the owner around 462.6 million of ETB - which is a significant amount when compared with the number of projects.

Identification and management on failure of cost were not exercised in different local construction partners of Ethiopia. As well no formal system of planning, mitigation and monitoring on failure of place at the project level. The following are some of the key reasons for project cost overrun, as researchers understood from the case study.

The first reason was the variations that happen throughout implementation. It was mainly caused from design output incompetence, and resultant extra completion project time and cost. As a result of inaccurate planning and insufficient investigation of the project during pre-construction phase of the projects, the actual earth material and rock scoured quantity was much more than predicted. The case study also shows that the lack of attention for the utility (due to the failed pipe structure, constructing an access road, retaining wall at cut sides, paved ditch along box cut sections) resulting major variation in quantities, leading to project schedule and cost overrun.

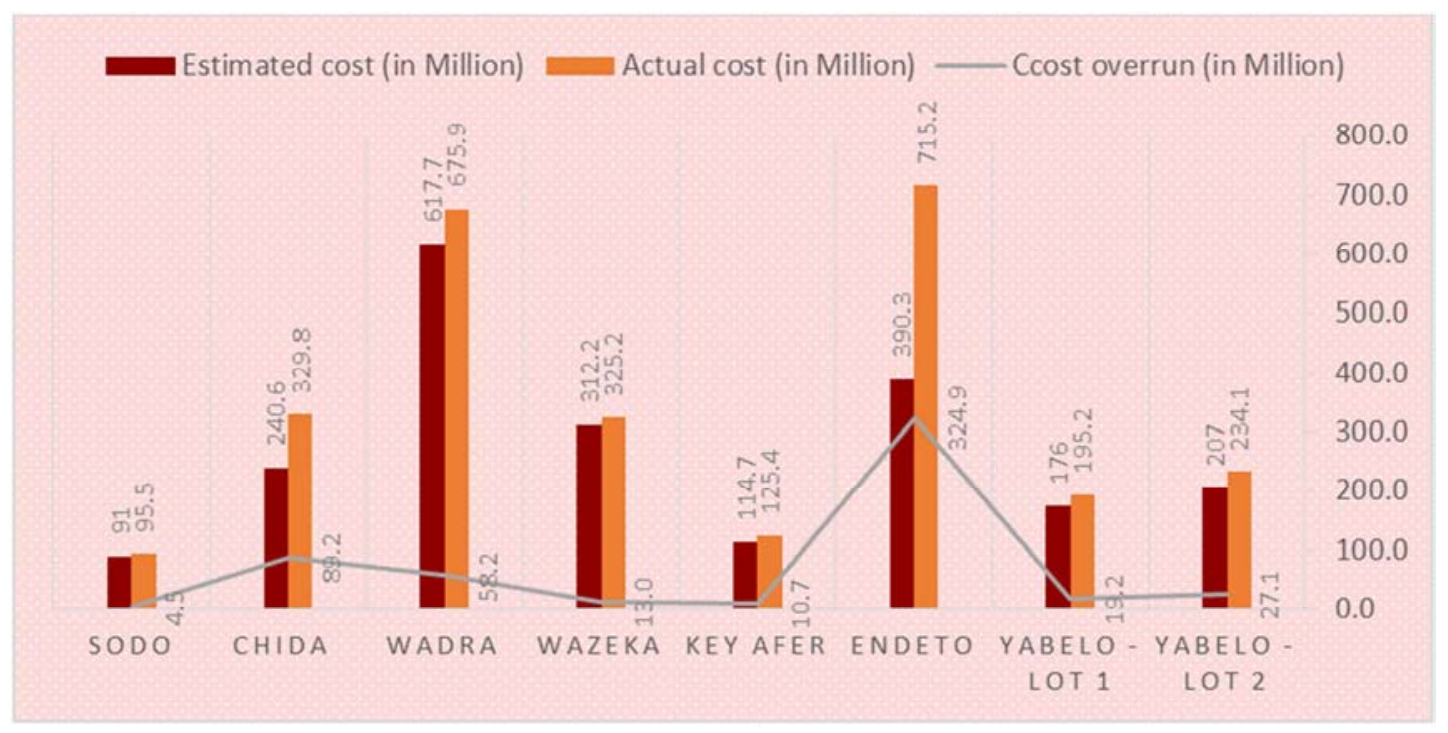

Figure 1. Magnitude of cost among projects.

The second reason is the problem of right of way acquirement, which is a fundamental component of the overall planning and implementation of road construction projects. The process was more difficult, need time, expensive and socially complex over the project. The interference of the extra stakeholders, other than community, the local government officials for the compensation, and lack of awareness of the community were the challenges that volatile the project cost.

The third reason is inadequate and delay of resources. Delayed in the supply of cement, skilled labor and machineries and breakdown of machineries have been a major bottleneck in road projects under this case study. Because of limited suppliers of construction machineries' and machineries' spare part that create intolerable idle time on projects. This leads the contracting company to pay for the employee without works. Both lack of cement and lack of skilled labor were the jam during the project execution. While the inadequate cement appeared due to limited cement manufacturing capacity and could not meet the supply schedule of various coexisting projects under execution by different governmental and private firms. Skilled and experienced project workforces are unusual assets for an organization and mostly, the migration of professionals was a common problem. Thus, to hold the available workforce and invite new talent, companies need to focus on compensations. 
These were led to slippage in achievement of critical resulted.

The last reason is material price escalation. Material price escalation was a business possibility faced by all contractors. In latest years, costs of vital inputs such as steel, cement, bitumen, fuel, etc. have fluctuated suddenly. The possibility of material cost fluctuation was a characteristic in projects, and to some extent was taken into consideration in the whole project cost estimate. However, the unpredictability in material prices escalation made estimate a challenge and leads to inaccurate forecasts. Moreover, the cost estimate adopts the project accomplishment as per the schedule and consider tolerable inflation rate. However, any interruption in project completion and the material price escalation made the initially estimated cost outdated which leading to cost overruns.

\subsection{Causes of Cost Overrun}

The collected survey data - questionnaire were processed and data code developed to undertake statistical data analysis. Thus, the descriptive statistical analysis has done to identify the factors causes cost overrun from a different perspective, from client, consultant and contractor view.

\subsubsection{Questionnaire Response Rate}

The survey through questionnaire conducted in eighteen (18) projects. A total of 54 questionnaires was distributed to the main parties (client, contractors and consultants) participated selected projects. For the three parties equally eighteen questionnaire distributed. Whereas, 45 questionnaires (83.3\% response rate) received. Tables 4 and 5 show the profile of the practitioners that responded to questionnaire on behalf of their companies and their perception to the problem of project cost overrun.

Table 4. The profile of the respondents.

\begin{tabular}{lll}
\hline Role & Frequency & Percent \\
\hline Project manager & 8 & 17.8 \\
Planning Engineer & 5 & 11.1 \\
Contract Engineer & 11 & 24.4 \\
Site Engineer & 9 & 20.0 \\
Office Engineer & 9 & 20.0 \\
Director & 3 & 6.7 \\
Total & 45 & 100.0 \\
\hline
\end{tabular}

In Table 5 shows the majority of the practitioner, nearly $56 \%$ rate that the problem of project cost overrun was very significant and around $29 \%$ of the practitioner rate that the project cost overrun was an extreme case. This implies that the problem of cost overrun was a sensitive issue in road construction projects.

Table 5. The problem of cost overrun as the respondents 'perception.

\begin{tabular}{lll}
\hline Weight & Frequency & Percent \\
\hline Not significant & 0 & 0 \\
Slightly significant & 1 & 2.2 \\
Moderately significant & 6 & 13.3 \\
Very significant & 25 & 55.6 \\
Extremely significant & 13 & 28.9 \\
Total & 45 & 100.0 \\
\hline
\end{tabular}

\subsubsection{Reliability Test}

Data from the independent category of the questionnaire were analyzed for its Cronbach $\alpha$ value. This was to confirm that the data collected are valid and reliable for advance analysis. Cronbach $\alpha$ value for overall data was 0.915 , and Table 6 shows the values of Cronbach $\alpha$ for each category of the factors are in the range of 0.830 to 0.929 . This interval was high when compared to cutoff value of 0.7 .

Table 6. Reliability test results.

\begin{tabular}{ll}
\hline Categories & Cronbach $\boldsymbol{\alpha}$ \\
\hline Client & 0.830 \\
Consultants & 0.928 \\
Contractors & 0.929 \\
Overall & 0.915 \\
\hline
\end{tabular}

In this study the questionnaire survey made to rate the factors, experienced by project owners, contractors and consultants, resulting in cost overruns in a project from the pre execution stage to the execution phase. A total of 48 factors which influencing cost overruns was identified and after some analysis 40 factors presented to respondents to rate. The factors are categorized under three general categories: the factors related to project management; factors related to the construction execution process and the factors related to the business environments. The respondents' evaluation for each factor was analyzed by using the percentage of maximum scoreor or relative importance weight method [51] and [33].

$$
P M s=\frac{M P s}{A s} * 100=\sum \frac{a_{i} n_{i}}{N a_{m}}
$$

Percentage of maximum score.

Where PMs $=$ percent of maximum score

MPs = maximum possible score

As $=$ Actual Score

Actual score, As $=$ Maximum scale $*$ Total respondents

$\mathrm{N}=$ number of respondents

$\mathrm{a}_{\mathrm{i}}=$ is a constant that expresses the weight given to the $\mathrm{i}^{\text {th }}$ response: $\mathrm{i}=1$ (not significant), 2 (slightly significant), 3 (moderately significant), 4 (very significant) and 5 (extremely significant)

$\mathrm{a}_{\mathrm{m}}=$ is a constant that expresses the maximum weight given to the $i^{\text {th }}$ response: $i_{5}=5$ (extremely significant)

$\mathrm{n}_{\mathrm{i}}=$ is the variable expressing the frequency of the ith response.

For instance, to compute the PMs (it is tabulated in Table 7) for Procurement preparation, Tendering and Tender evaluation;

Whereas: $\mathrm{F}=$ represents the frequency

$\mathrm{P}=$ the product of value (column 2) and the frequency, $\mathrm{F}$ (Column 3, 5 and 7).

From Table 7 the Maximum possible score, MPs for each factor is the summations of products of value and frequency. In this case the MPs for Procurement Preparation is 33, for Tendering 34 and for Tender evaluation 30. 
Table 7. Maximum possible score manipulation.

\begin{tabular}{llllllll}
\hline \multirow{2}{*}{ Measurement Scale } & \multirow{2}{*}{ Value } & \multicolumn{2}{c}{ Procurement Preparation } & \multicolumn{2}{c}{ Tendering } & \multicolumn{2}{c}{ Tender Evaluation } \\
\cline { 3 - 8 } & & $\boldsymbol{F}$ & $\boldsymbol{P}=\left(\right.$ Value $\left.^{*} \boldsymbol{F}\right)$ & $\boldsymbol{F}$ & $\boldsymbol{P}=\left(\right.$ Value $\left.^{*} \boldsymbol{F}\right)$ & $\boldsymbol{F}$ & $\boldsymbol{P}=\left(\right.$ Value $\left.^{*} \boldsymbol{F}\right)$ \\
\hline Not significant & 1 & 4 & 4 & 2 & 2 & 2 \\
Slightly significant & 2 & 2 & 4 & 5 & 10 & 7 & 14 \\
Moderately significant & 3 & 3 & 9 & 2 & 6 & 2 & 6 \\
Very significant & 4 & 4 & 16 & 4 & 16 & 2 & 8 \\
Extremely significant & 5 & 0 & 0 & 0 & 0 & 0 & 0 \\
Total, $(\Sigma)$ & & & 33 & & 34 & 30 \\
\hline
\end{tabular}

The PMs, Percentage of Maximum score is computed hereunder.

Actual score, As $=$ Maximum scale $*$ Total respondents From(3)

$$
\text { Actual score, } \text { As }=5 * 13=65
$$

Procurement Preparation, PMs $=\frac{33}{65} * 100=51 \%$

From Eq. (2).

In similar fashion the percentage of maximum score was computed for the other factors depending on their groups and number of respondents.

\section{i. Project Management Related Factors}

Each project faces challenges. These can be various and their influence can be varied depending on the scope of the project. Project management might support to identify the unrealistic nature of the project, and specify that it should be corrected or improved. While poor project management causes the failure of resources to achieve the project goal, either in terms of cost or time or both, which is overruns [55].

The practitioner response rate evaluation for all factors related to project management were presented here from the client, consultants and contractors perception.

\section{A. Client's Perception}

Lack of coordination at the design phase, cost underestimation and lack of experience of technical consultants and Contractors were the primary reason for cost overruns, nearly scores $71 \%, 67 \%$ and $66.9 \%$ of maximum percentage respectively.

Figure 2 shows that the score of each factor related to the project management. The graph indicates that lack of coordination at design phase have maximum score or the respondents give a priority for this factor as a main reason for cost overruns. This indicates that in a study area of this research there was a gap on the design developments of the road projects. Different study shows that the selection of the designer and creating the design criteria is a major factor in the project's success. Besides considering the scope of the projects with required utility by itself needs approaches of multi-disciple [48] and [56]. This gap indicate that the project managers lag on the handling of the process of coordinating the design.

Simultaneously the cost under estimation was a primary factor next to the design gaps, according to the results of this survey. Past findings shows that cost underestimation is common in infrastructure developments, particularly in developing country [31]. It come from the improper planning and bias in the project implementation related to the policy implication. Also the cost of a project underestimated might be to get funding from the donors or might be for the acceptance of the project.

Both the design and cost under estimation mostly undertaken in the pre-construction phases. Consistent with this study lack of coordination at design phase was related to scope management and the cost underestimation was included under the cost managements. In reality, there was a gap for project managers to incorporate the gaps at the pre-construction phase of the project in case of Ethiopia. These leads the managers to create an obstacle in the management process.

Lack of experience of technical consultants and Contractors as well as Schedule delay and change were the next highest scored factors for cost overruns. Both weight nearly $66.5 \%$ and $66 \%$ of the maximum percentage score as client rate.

Technically inexperienced consultant creates a failure, design lack, which misleads the contractors. As different study shows that the problem of inexperienced technical consultants and the capability of the contractors are the issue of the developing countries. For instance, if the consultants are not technically well, the activities of the contractors might be out of the project objectives. In addition to this the incapability of the contractors leads the projects for delay in resources allocation, lack of managing the activities. All this affects the project cost due to lack the management process of the project manager.

\section{B. Consultants Perception}

Cost Underestimation; inadequate review of contract documents and lack of coordination at design phase were primary factors for project cost overrun as consultants' perception, nearly score $84 \%, 83 \%$ and $81 \%$ of maximum percentage.

The statistical analysis of consultant respondents' supports the reflection of the clients' perception, putting the cost underestimation as severe problems in project cost overrun. From different study cost underestimation occurs due to inaccuracy of estimating and project size, estimator's experience, imaginative ability and a wide range of assumption. In addition, increase cost of construction materials, change in foreign exchange rate (for imported materials), change orders and/or lack of control on excessive change orders mainly play a great role. The projects are also underestimated for the acceptance of the projects, due to higher officials or by the funding agency interests.

From the figure 2 an inadequate review of contract documents is the other factors which identified as significant 
factors by the consultants' practitioner. It occurs due to lack of complete planning and limited ability of project managers to assess all potential risks.

\section{Contractors Perception}

Delay in supply of raw materials and equipment; lack of cost planning/ monitoring during pre- and post-construction stages and payment delay are the primary reason for cost overrun as the contractor's respondent's judgment, scores $79 \%, 73 \%$ and $71 \%$ of maximum percentage.

The results of figure 2 shows that delay of raw materials and equipment were the dominant factors which lead the projects to cost flooded. Obviously, in most of the construction projects the materials cost covers nearly $60 \%$ of the project costs [57]. If it is not properly available on time it leads the project to delay - which incite the projects for cost overruns. Plus to this, the insufficient amount of equipment, the relationships with available equipment and the skilled manpower have direct impacts for the delay of raw materials.

From this survey what is observed the project raw materials and equipment were dominated by a few suppliers, especially for materials imported. For instance, the suppliers for construction machineries spare part is a few suppliers in Ethiopia. On the other hand, the Ethiopia labors mostly motivating way was by means compensation of wages. The other trend like training or education were not practiced as a means of motivation.

Furthermore, the public procurement practice in Ethiopia is the predetermined completion time and lower cost tender award system, direct award practices in the case of locally financed projects and procurement of works as part of procurement of services [54]. This also create the difficulties on the selection of technically competent contracting parties.

Effective planning becomes routine when planning is an integral part of the company's culture. This begins with commitment of top management, continues with communication of that commitment to mid-level managers, and come to be imbedded when every employee relates clearly to the company's goals. For instance, The Stanford Research Institute did the outcomes of planning before some years ago, "finding that company that supported planning programs experienced superior growth rates when compared to companies that did not" [58]. While Lack of cost planning/ monitoring during pre- and post-construction phasses are the primary factors according to this survey results of contractors' respondents.

The Spearman rank correlation coefficient for project management related fuctors.

In Table 8 below, the Spearman's coefficient of correlation (or rank correlation) of relationships of the respondents is presented. The coefficient shows the extent to which the two or more sets of agreement, which is the level of similarity or dissimilarity among the three groups (client, consultant and contractor). The correlation coefficient between client and consultant was 0.70 with P-value (single - tailed test) $=0.006$. The P-value is below the level of significance, $\alpha=0.05$, which indicates there are a significant association between client and consultant. While the correlation coefficient concerning the client and contractors is 0.40 (show moderate significance) per P-value (single - tailed test) $=0.03$. Whereas the $\mathrm{p}$-value is below the value of specified significance level, $\alpha=0.05$, so there is a significant relationship between client and contractors with this confidence interval. Furthermore, the correlation coefficient between contractor and consultant equals to 0.77 with P-value (single - tailed test) $=0.01$. The $\mathrm{P}$-value is less than the level of significance, $\alpha=0.05$, so there is a significant relationship between consultant and contractor.

Table 8. Correlation test of the manager's skill attributes.

\begin{tabular}{lll}
\hline Groups & rho & P-Value \\
\hline Client \& Consultants & 0.70 & $0.006^{*}$ \\
Client \& Contractors & 0.035 & $0.03^{*}$ \\
Consultants \& Contractors & 0.77 & $0.01 *$ \\
$*$ Correlation is significant at 0.05 significance level & \\
\hline
\end{tabular}

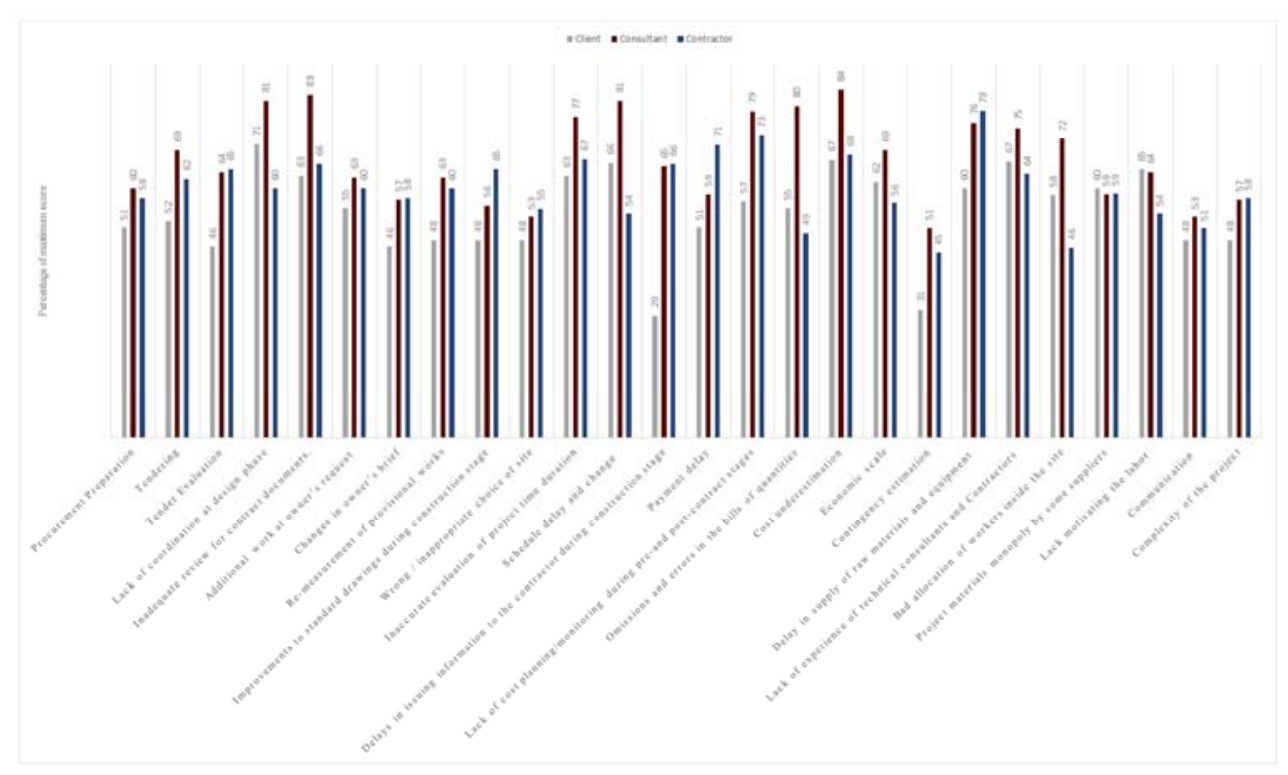

Figure 2. Project management related factors. 


\section{ii. Project Execution process related Factors}

The execution process consists of the activities performed to realize the project's goal and recognize the projected benefits. Primarily the activities of mobilization and utilization of capital and skilled personnel, materials, and equipment to assemble materials and equipment on a specific site in accordance with drawings, specifications, and contract documents are the main activities.

\section{A. Clients Perception}

Lack of training, Benefit realization and production supports were the primary reason of cost overrun at the execution processes of the projects, scores 55\%, 54\% and 52\% maximum percentages respectively as client's perception.

According to the survey results of this study, figure 3, all respondents of client, consultant and contractors agree that lack of training was the primary reason for cost overrun on road construction projects in Ethiopia. Different researchers approves that companies in the business world are continuously concerned with improving their bottom line by increasing total profit [58]. This can be realized through different approach or philosophy of the company. Different researchers agree that training for the employees takes the ranks to improve the company's product and the performance. For instance, special training for an individual increase competition for selection - it becomes a strong motivator for outstanding performance of the employees. The ongoing training for employee increase the technical quality and skill.

Benefit realization and product supports are the other reason for the cost overrun as the survey shows, Figure 3. It is understood that realizing benefit for employees is correspondingly increased motivation and staff employee settlement on the company.

\section{B. Consultants and Contractors Perception}

Lack of training, Implementation Process or Bureaucrat and Benefit realization were the primary reason of cost overrun at the execution processes of the projects, their scores $79 \%, 72 \%$ and $63 \%$ as consultant and $62 \%, 56 \%$ and $51 \%$ as contractor's judgments.

Figure 3 summarize that implementation process or bureaucrat is the primary reason for the project cost overrun next to lack of trainings as the consultant and contractor practitioner.

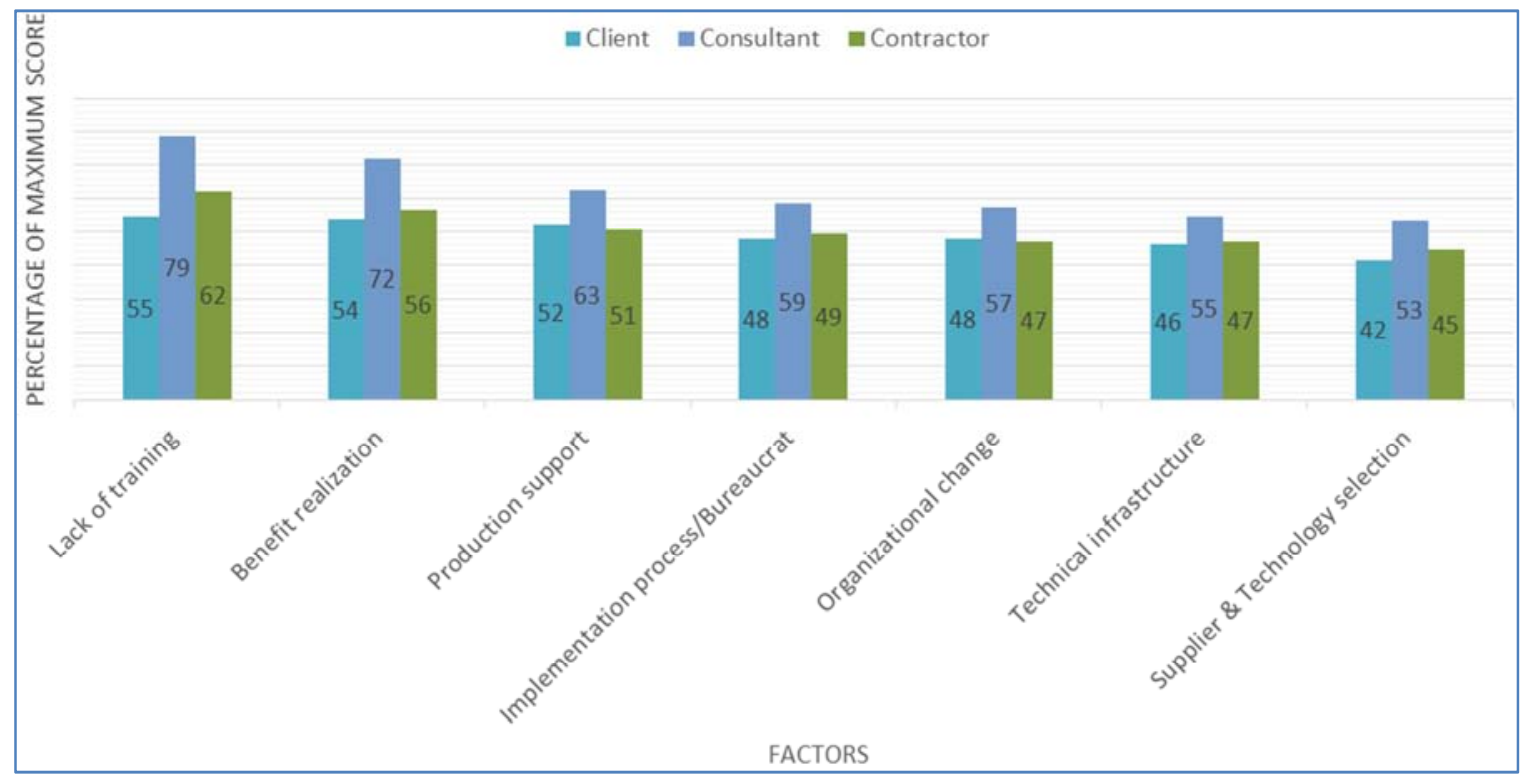

Figure 3. Project execution process factors score.

The Spearman rank correlation coefficient for Project execution process set.

As presented in Table 9, the correlation coefficient for the project execution factors between client and consultant was 0.98 with $\mathrm{P}$-value (single - tailed test $)=0.01$. The P-value is less than the specified significance level, $\alpha=0.05$, which indicates there is a strong significant relationship between client and consultant ratings. Moreover, the correlation coefficient relating to the client and the contractor was 0.97 per P-value (single - tailed test) $=0.01$. Which implies that the $\mathrm{p}$-value is smaller than the value of significance level, $\alpha=$ 0.05 , so there is a significant relationship between client and contractors rank with this confidence interval. On the contrary, the correlation coefficient between contractor and consultant equals to 0.98 with P-value (single - tailed test) $=0.01$. The $\mathrm{P}$-value is lower than the level of significance, $\alpha=0.05$, thus there is a significant rating agreement between consultant and contractor rank.

Table 9. Correlation test of the project execution attrib 'utes.

\begin{tabular}{lll}
\hline Groups & rho & P-Value \\
\hline Client \& Consultants & 0.98 & $0.009^{*}$ \\
Client \& Contractors & 0.96 & $0.01 *$ \\
Consultants \& Contractors & 0.98 & $0.009^{*}$ \\
*Correlation is significant at 0.05 significance level & \\
\hline
\end{tabular}

iii. Business Environments Related Factors

Depending on their country level of development or economic scale, different project costs will be influenced by 
factors beyond the control - environmental factors. These environmental factors weigh up, because it will affect project success. The reality of business environments, due to the behavior of the Ethiopian market price - which is uncontrolled free market policy, there are fluctuation of the cost of construction materials.

\section{Client, consultants' and Contractors' Perception}

Material price fluctuation and Compotators (Suppler) are the primary factors in business environments related factors from a client, consultants' and contractors' judgment.
The survey, Figure 4, shows that material price fluctuation is the predominant factors of the project cost overrun. Competitors of suppliers and strategic alignment are the other factors influencing cost overrun. In Ethiopian condition the supplier of construction materials are a few in number that also create fluctuation of the project costs. Simultaneously the strategic alignment of the owners has also significant impacts. For instance, the interests of the higher officials and the middle officials', and funding agency influences the project cost.

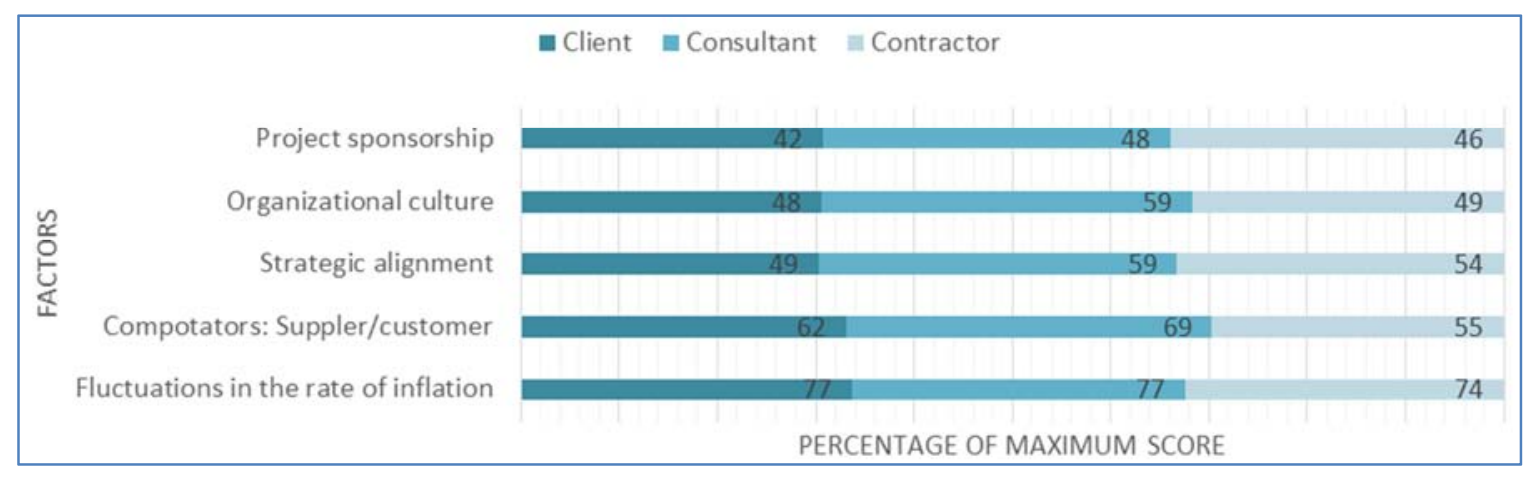

Figure 4. Business environments factors score as consultants' judgment.

The Spearman rank correlation coefficient for Business Environment set

Table 10 show that, the computed correlation coefficients among all the categories of respondent were tabulated. The correlation coefficient and the P-value (single - tailed test) $=$ 0.02 of client and consultant, client and contractor, and the consultant and contractors were 0.98. The correlation coefficient is high and $\mathrm{P}$-value is also lower than the significance level, $\alpha=0.05$. These implies that there are significant correlation ratings among the three parties.

Table 10. Correlation test of the business environment attributes.

\begin{tabular}{lll}
\hline Groups & rho & P-value \\
\hline Client \& Consultants & 0.98 & 0.02 \\
Client \& Contractors & 0.98 & $0.02 *$ \\
Consultants \& Contractors & 0.98 & $0.02 *$ \\
\hline
\end{tabular}

* Correlation is significant at 0.05 significance level

\subsubsection{Overall Ranking of Factors}

From equation 2, the percentage of the maximum score, PMs for all the factors were computed first for the client, consultant, and contractor categories separately, and then for overall samples. Table 6.8 shows the calculated PMs and rankings for 40 attributes in all four categories. The next portions discuss the significance of some of the key attributes across all three categories with respect to the overall percentage of maximum score shown in the first column.

As seen in Table 11, the overall ranking shown that material price fluctuation is one of the most significant factors (PMs = $76.0 \%$ ) that influence cost performance in projects. Furthermore, the clients share the same views. While both consultants and contractors ranking this factors in ninth and second respectively. This implies that how the consultants looking material price as secondary factors. In comparison the cost underestimation is supposed to be the most significant attributive's from the consultants' perspective, which is ranked in second overall position. Assumed that the consultant's intention is primarily motivated to the detail cost estimation for each activity of the projects. Delay in supply of raw materials and equipment is the most significant factors from the contractors' perspective, while it was ranked in third pn overall position. It shows how the contractors bothering to get the construction raw material.

Past findings argue that these factors - material price fluctuation, cost underestimation and delay of raw materials and equipment are the most common factors influencing cost overrun, mainly in developing countries [10], [26] and [31]. Market condition is the uncontrolled condition, but it needs proper planning and scheduling. Once properly planned and scheduled not only the price fluctuation of the materials, but also the delay of raw materials solved.

Inadequate review of drawings and contract documents (PMs $=70.7 \%$ ) was the fourth most significant attribute as overall position, which was a difficulty in the performance of the project costs. While the consultants rank this factor as the second most significant, and both the client and contractors rank in seventh position. The client's significantly trust on consultant's performance in most current projects. However, paucity of contractor's is related to detaile understanding of the project design and specifications often leads to failure. This possibly generates conflicts among all three parties, which inspire to additional costs in the project. The implication of clients and contractor's shows that both give priority for the coordination at design phases and payment delay respectively. Findings of [19] suggest that, all functional teams were not involved in the conceptualization stage, which leads to inadequate assessments of risk, shows the collaboration level of 
project owners and contractors. But if the contract documents are properly reviewed that fill the gaps.

Table 11. Factors that reasons for cost overrun.

\begin{tabular}{|c|c|c|c|c|c|c|c|c|}
\hline \multirow{2}{*}{ Factors } & \multicolumn{2}{|c|}{ Overall } & \multicolumn{2}{|c|}{ Client } & \multicolumn{2}{|c|}{ Consultant } & \multicolumn{2}{|c|}{ Contractors } \\
\hline & PMs & Rank & PMs & Rank & PMs & Rank & PMs & Rank \\
\hline Material price fluctuation & 76.0 & 1 & 76.9 & 1 & 77.3 & 9 & 74.1 & 2 \\
\hline Cost underestimation & 72.9 & 2 & 66.2 & 3 & 84.0 & 1 & 68.2 & 5 \\
\hline Delay in supply of raw materials and equipment & 72.4 & 3 & 60.0 & 11 & 76.0 & 11 & 78.8 & 1 \\
\hline Inadequate review and contract documents. & 70.7 & 4 & 63.1 & 7 & 82.7 & 2 & 65.9 & 7 \\
\hline Lack of coordination at design phase & 70.2 & 5 & 70.8 & 2 & 81.3 & 4 & 60.0 & 14 \\
\hline Lack of cost planning/monitoring during pre-and post-contract stages & 70.1 & 6 & 56.9 & 15 & 78.7 & 7 & 72.9 & 3 \\
\hline Lack of experience of technical consultants & 68.0 & 8 & 66.2 & 4 & 74.7 & 12 & 63.5 & 11 \\
\hline Schedule delay and change & 66.7 & 9 & 66.1 & 5 & 81.2 & 5 & 54.1 & 26 \\
\hline Inaccurate quantity take-off & 65.8 & 10 & 58.5 & 13 & 82.5 & 3 & 56.5 & 20 \\
\hline Lack of training & 65.3 & 11 & 53.8 & 18 & 78.6 & 8 & 62.4 & 12 \\
\hline Economic scale & 62.2 & 12 & 61.5 & 9 & 69.3 & 15 & 56.5 & 20 \\
\hline Tendering & 61.8 & 13 & 52.3 & 20 & 69.3 & 15 & 62.4 & 12 \\
\hline Omissions and errors in the bills of quantities & 61.3 & 14 & 55.4 & 16 & 80.0 & 6 & 49.4 & 32 \\
\hline Lack motivating the labor & 60.4 & 16 & 64.6 & 6 & 64.0 & 20 & 54.1 & 26 \\
\hline Additional work at owner's request & 59.6 & 17 & 55.4 & 16 & 62.7 & 22 & 60.0 & 14 \\
\hline Tender Evaluation & 59.1 & 18 & 46.2 & 33 & 64.0 & 20 & 64.7 & 9 \\
\hline Project materials monopoly by some suppliers & 59.1 & 18 & 60.0 & 11 & 58.7 & 26 & 58.8 & 16 \\
\hline Implementation process/Bureaucrat & 59.1 & 18 & 47.7 & 25 & 72.0 & 13 & 56.5 & 20 \\
\hline Bad allocation of workers inside the site & 58.2 & 21 & 58.5 & 13 & 72.0 & 13 & 45.9 & 37 \\
\hline Compotators: Suppler/customer & 58.2 & 21 & 61.4 & 10 & 58.7 & 26 & 55.3 & 24 \\
\hline Improvements to standard drawings during construction stage & 56.9 & 23 & 47.7 & 25 & 56.0 & 35 & 64.6 & 10 \\
\hline Procurement Preparation & 56.4 & 24 & 50.8 & 22 & 60.0 & 25 & 57.6 & 17 \\
\hline Re-measurement of provisional works & 55.6 & 25 & 47.7 & 25 & 68.0 & 18 & 50.6 & 29 \\
\hline Wrong / inappropriate choice of site & 55.6 & 25 & 47.7 & 25 & 62.7 & 22 & 55.3 & 24 \\
\hline Benefit realization & 55.6 & 25 & 53.8 & 18 & 62.7 & 22 & 50.6 & 29 \\
\hline Organizational culture & 55.6 & 25 & 47.7 & 25 & 69.3 & 15 & 49.4 & 32 \\
\hline Delays in issuing information to the contractor during construction stage & 55.1 & 29 & 29.2 & 40 & 65.3 & 19 & 65.7 & 8 \\
\hline Complexity of the project & 54.7 & 30 & 47.7 & 25 & 57.3 & 32 & 57.6 & 17 \\
\hline Changes in owner's brief & 54.2 & 31 & 46.2 & 33 & 57.3 & 32 & 57.6 & 17 \\
\hline Production support & 51.6 & 34 & 52.3 & 20 & 53.3 & 37 & 49.4 & 32 \\
\hline Communication & 50.7 & 35 & 47.7 & 25 & 53.3 & 37 & 50.6 & 29 \\
\hline Organizational change & 49.8 & 36 & 47.7 & 25 & 57.3 & 32 & 44.7 & 39 \\
\hline Supplier \& Technology selection & 49.3 & 37 & 41.5 & 37 & 58.7 & 26 & 47.1 & 35 \\
\hline Technical infrastructure & 49.3 & 37 & 46.2 & 33 & 54.7 & 36 & 47.1 & 35 \\
\hline Project sponsorship & 45.3 & 39 & 41.5 & 37 & 48.0 & 40 & 45.9 & 37 \\
\hline Contingency estimation & 42.7 & 40 & 30.8 & 39 & 50.7 & 39 & 44.7 & 39 \\
\hline
\end{tabular}

Spearman rank correlation coefficient of overall rank

In the Table 12 correlation coefficient among the categories of client, consultant and contractor for overall ranked were presented. The correlation coefficient of client and consultant was 0.71 with $\mathrm{P}$-value (single - tailed test) of 0.006 . The $\mathrm{P}$-value is below the significance level, $\alpha=0.05$ and $\rho$ is above the limited value 0.7 , which suggests that, there were a significant association regarding client and consultant rank. Besides the correlation coefficient concerned with the client and contractors was 0.44 per P-value (single - tailed test) of 0.003 . Which implies that the p-value is lower than the significance level, $\alpha=0.05$, and $\rho$ value is found in moderate significance, therefore there was significant correlation between client and contractor rank with this confidence interval. On the other hand, the correlation coefficient of contractor and consultant is 0.51 with P-value (single - tailed test $)=0.004$. The P-value is lower than significance level, $\alpha=$ 0.05 , shows a significant agreement between consultant and contractor rank.

Table 12. Correlation test of the overall attributes.

\begin{tabular}{lll}
\hline Groups & rho & P-Value \\
\hline Client \& Consultants & 0.71 & 0.006 \\
Client \& Contractors & 0.44 & 0.004 \\
Consultants \& Contractors & 0.51 & 0.005 \\
\hline
\end{tabular}

\section{Conclusion and Recommendation}

Based on the three major construction parties (client, consultant and contractor), the principal factors that affect project cost performance throughout the pre-construction and construction phases of projects were investigated. From descriptive analysis, 40 selected factors related to project cost were ranked using the percentage of the maximum score as jedgments of clients, consultants, and contractors working on 
Ethiopian road construction projects. These 40 selected factors were categorized as the project management, project execution and project environment related factors.

A combination of questionnaire surveys and case study (archival review) have been used to provide helpful evidence on issues related to the project cost performance. Popularity of the problem of project cost overrun, rating the significance of identified factors, enlarging the top rated factors and the most commonly used mitigating techniques were main issues.

One of the basic outcomes, that project material price fluctuation plays a significant role on project cost status. The client, consultants and contractor's ignorance of these factors potentially affects the overall project cost performance.

Finally, it is commonly known that projects that are well-managed have a better project performance. The management of data or archive of Ethiopian Road Authority show that it is habitually not stored well or the culture of ducumetation information was very low. Thus, this study recommends that the management of information or documentation/archive in Ethiopian Road Authority need standardized approach.

From the experience of different researcher's, the project cost performance is associated with the mode of delivery. Investigating the appropriate mode of delivery in road project needs further researches.

For a large public works program with construction cost is bigger, the problem of construction costs performance can be improved through a widespread review of contractibility that need extra investment conducting to reviews.

While this research finding has some limitations. The data was collected from only eighteen projects and main parties (client, consultant and contractors) were included.

\section{References}

[1] R. R. Venkataraman and J. K. Pinto, Cost and value management in projects, New Jersey: John Wiley \& Sons, Inc., 2008.

[2] W. Turkey, "Risk Factors Leading to Cost Overrun in Ethiopian Federal Road Construction Projects and Its Consequences," Addis Ababa, 2011.

[3] B. F. E. J. E. M. a. B. v. W. Chantal C. Cantarelli, "Cost overruns in Large-Scale Transportation Infrastructure Projects: Explanations and Their Theoretical Embeddedness," European Journal of Transport and Infrastructure Research, pp. 5-18, 2010 .

[4] J.-K. Lee, "Cost Overrun and Cause in Korean Social Overhead Capital Projects: Roads, Rails, Airports, and Ports," Journal of Urban Planning and Development @ ASCE, pp. 59-62, 2008.

[5] J. K. W. W. Garry D. Creedy Martin Skitmore, "Evaluation of Risk Factors Leading to Cost Overrun in Delivery of Highway Construction Projects," CONSTRUCTION ENGINEERING AND MANAGEMENT @ ASCE, pp. 535-536, 2010.

[6] P. C. A. S. S. L. A. K. C. S. H. a. F. L. M. Abhishek Bhargava, "Three-Stage Least-Squares Analysis of Time and Cost Overruns in Construction Contracts," Journal of Construction
Engineering and Managemen, pp. 1216-17, 2010.

[7] M. K. S. H. a. S. L. B. Bent Flyvbjerg, "What Causes Cost Overrun in Transport Infrastructure Projects?," Transport Reviews, pp. 3-18, 2004.

[8] H. Doloi, "Cost Overruns and Failure in Project Management: Understanding the Roles of Key Stakeholders in Construction Projects," Journal of Construction Engineering and Management (C) ASCE, pp. 267-279, 2013.

[9] Y. Rosenfeld, "Root-Cause Analysis of Construction-Cost Overruns," Journal of Construction Engineering and Management (C) ASCE, pp. 5-9, 2013.

[10] G. G. a. M. B. Thillai A. Rajan, "PPPs and Project Overruns: Evidence from Road Projects in India," Journal of Construction Engineering and Management (C) ASCE, pp. 3-9, 2013.

[11] A. K. R. M. M. S. A. M. a. C. S. D. Jennifer S. Shane, "Construction Project Cost Escalation Factors," Journal of Management in Engineering CASCE, pp. 221-229, 2009.

[12] M. P. M. H.-S. L. M. J. A. N. K. a. a. B. S. Sae-Hyun J, "Military Facility Cost Estimation System Using Case-Based Reasoning in Korea," COMPUTING IN CIVIL ENGINEERING (C) ASCE, pp. 218-231, 2011.

[13] R. R. A. I. F. a. I. F. A. Sang C. Lhee, "Prediction of Financial Contingency for Asphalt Resurfacing Projects using Artificial Neural Networks," Journal of Construction Engineering and Management, pp. 22-30, 2012.

[14] M. a. A. CharlesT. Jahren, "PREDICTORS OF COST-OVERRUN RATES," Journal of Construction Engineering and Management, pp. 548-551, 1990.

[15] a. T. R. A. Surya Sudheer Meduri, "Unit Costs of Public and PPP Road Projects: Evidence from India," Journal of Construction Engineering and Management (C) ASCE, pp. 35-43, 2013.

[16] R. U. F. a. S. M. A. Nida Azhar, "Cost Overrun Factors In Construction Industry of Pakistan," in Advancing and Integrating Construction Education, Research \& Practice, Karachi, 2008.

[17] H. A. a. D. T. Ruth Apolot, "An Investigation into the Causes of Delay and Cost Overrun in Uganda's Public SectorConstruction Projects," in Second International Conference on Advances in Engineering and Technology, Kampala, 2010

[18] D. J. E. H. W. a. P. D. Peter E. D. Love, "Rework in Civil Infrastructure Projects: Determination of Cost Predictors," Journal of Construction Engineering and Management, pp. 275-282, 2010.

[19] S. M. V. a. F. Najafi, "COST AND TIME OVERRUNS IN HIGHWAY CONSTRUCTION," in 4th Transportation Specialty Conference of the Canadian Society for Civil Engineering, Montréal, Québec, 2002.

[20] S. K. A. S. Ali, "Cost Performance for Building Construction Projects in Klang Valley," Journal of Building Performance, pp. 111-116, 2010.

[21] A. Alhomidan, "Factors Affecting Cost Overrun in Road Construction Projects in Saudi Arabia," International Journal of Civil \& Environmental Engineering, pp. 2-4, 2013. 
[22] M. A. Kasimu, "Significant Factors that Causes cost Overruns in Building Construction Project in Nigeria.," INTERDISCIPLINARY JOURNAL OF CONTEMPORARY RESEARCH IN BUSINESS, pp. 777-779, 2012.

[23] J. M. Al-Najjar, "Factors Influencing Time and Cost Overruns on Construction Projects in the Gaza Strip," 2008.

[24] A. B. Ibrahim Mahamid, "Cost Deviation in Road Construction Projects: The Case of Palestine," Australasian Journal of Construction Economics and Building, pp. 58-71, 2012.

[25] P. m. I. PMI, "Study on Project Schedule and Cost Overruns," Project management Institute, 2012.

[26] P. M. I. PMBIK, A guide to project management body of knowledge: PMBOK guide.- 3rd ed, Pennsylvania: project management Institute, Inc., 2004.

[27] D. Cartlidge, Quantity Surveyor's Pocket Book 1st ed, London: Elsevier Ltd., 2009.

[28] G. A. S. S. K. Richard H. Clough, Construction project management : a practical guideto field construction management 5th ed, New Jersey: John Wiley \& Sons, Inc., 2009.

[29] A. C. T. a. J. G. Rees, Civil Engineering Project Management 4th ed., Burlington: Elsevier Butterworth-Heinemann, 2004.

[30] J. M. a. W. Hughes, Construction Contracts: Law and Management 3rd ed., London: Spon Press, 2000.

[31] E. A. Gamez, "RISK ASSESSMENT FOR INTERNATIONAL DEVELOPMENT PROJECTS: OWNER'S PERSPECTIVE," Northeastern University, Boston, 2009.

[32] R. Singh, "Cost and Time Overruns in Infrastructure Projects: Extent, Causes and Remedies," Centre for Development Economics, vol. 181, 2009.

[33] D. Tilk, "Project Success through Project Risk Management," $112012011 . \quad$ [Online]. Available: http://www.pwc.com/ca/en/controls/program-project-services/ project-risk-management.jhtml\#.

[34] S. P. Shruti Wadalkar, "Role of Project Manager from the Client's Side on the Performance of a Construction Project," International Journal of Engineering and Advanced Technology (IJEAT), p. 340, 2012.

[35] C. J. a. J. Burger, "Project Management Methodology in Human Resource Management," JOURNAL Fall/winter, pp. 25-30, 2005.

[36] D. E. Gray, Doing Research in the Real World, 1st ed., London: SAGE Publications, 2004

[37] C. Kothari, Research Methodology: Methods and Techniques, New Delhi: New Age International (P) Ltd., 2004.

[38] S. G. Naoum, Dissertation Research and Writing for Construction Students, Amsterdam: Elsevier Ltd, 2007.

[39] W. World Bank, "Curbing Fraud, Corruption, and Collusion in the Roads Sector," The World Bank, Washington DC, 2011.

[40] G. D. Oberlender, Project Managment for Engineering and Construction, Singapore: McGraw-Hill, 2000.

[41] K. K. Chitkara, Construction Project management: Planning, Schedule and controling 2nd ed, New Delhi: Tata
McGraw-Hill, 2004.

[42] A. H. Yimam, "PROJECT MANAGEMENT MATURITY IN THE CONSTRUCTION INDUSTRY OF DEVELOPING COUNTRIES (THE CASE OF ETHIOPIAN CONTRACTORS )," University of Maryland, College Park (Unpublished Master Thesis), Maryland, 2011.

[43] B. G. M. S. L. a. K. C. S. Claire Bordat, "An Analysis of Cost Overruns and Time Delays of INDOT Projects," Unpublished, West Lafayette, 2004.

[44] F. Nega, "Causes and Effects of Cost Overrun on Public Building Construction Projects in Ethiopia," Unpublished Master thesis@AAU, Addis Ababa, 2008.

[45] AACE, SKILLS \& KNOWLEDGE OF COST ENGINEERING, Morgantown: AACE International, 2004.

[46] I. A. Rahman, A. H. Memon and A. T. A. Karim, "Relationship between Factors of Construction Resources Affecting Project Cost," Canadian Centerof Science and Education, pp. 70-74, 2013.

[47] B. Flyvbjerg, M. k, SKAMRISHOLMl and S. BUHL, "How common and how large are cost overruns in transport infrastructure projects?," TRANSPORTREVIEWS, pp. 85-86, 2003.

[48] N. Kasim, C. Anumba and A. Dainty, "Improving materials management practices on fast-track construction projects," in 21st Annual ARCOM Conference, London, 2005.

[49] C. C. Cantarelli, B. v. Wee, E. J. E. Molin and B. Flyvbjerg, "Different Cost Performance: Different Determinants? The Case of Cost Overruns in Dutch Transportation Infrastructure Projects," Transport Policy, p. 88-95., 2012.

[50] J. Y. Lin and D. Doemeland, "Beyond Keynesianism Global Infrastructure Investments in Times of Crisis," Policy Research Working Paper, 2012.

[51] A. A. A. Azis, A. H. Memon, I. A. Rahman and A. T. A. Karim, "Controlling Cost Overrun Factors in Construction Projects in Malaysia," Applied Sciences, Engineering and Technology, pp. 2621-2629, 2013.

[52] C. Cantarelli, "Cost Overruns in Large-Scale Transport Infrastructure Projects," The Netherlands TRAIL Research School, Delft, 2011.

[53] A. Enshassi, S. Mohamed and S. Abushaban, "FACTORS AFFECTING THE PERFORMANCE OF CONSTRUCTION PROJECTS IN THE GAZA STRIP," JOURNAL OF CIVIL ENGINEERING AND MANAGEMENT, vol. 15, no. 3, p. 269-280, 2009.

[54] D. Baccarini and A. Collins, "The Concept of Project Success What 150 Australian project managers think," Unpublished, pp. 1-2, 2001 .

[55] K. N. Jhn and K. C. Iyer, "Critical Factors Affecting Quality Performance in Construction Projects," Total Quality Management, pp. 1156-1169, 2006.

[56] I. A. R. a. A. A. A. A. Aftab Hameed Memon, "Preliminary Study on Causative Factors Leading to Construction Cost Overrun," International Journal of Sustainable Construction Engineering \& Technology, pp. 58-68, 2011.

[57] M. W. Jekale, "Risk Management for Construction Projects," EACE Journal, pp. 1-2, 2008. 
[58] I. A. R. A. A. A. A. Hameed Memon, "Time and Cost Perfomance in Costruction Projects inSouthern and Cenrtal Regions of Penisular Malaysia," International Journal of Advances in Applied Sciences (IJAAS), pp. 47-51, 2012.

[59] M. Ibrahim and B. Amund, "Cost Overrun Causes in Road Construction Projects: "Consultants' Perspective"," in 2011 2nd International Conference on Construction and Project Management, Singapore, 2011.

[60] W. M. Jekale, "Performances for Public Construction Projects in (Least) Developing Countries: Road \& Educational Building Projects in Ethiopia," Doctoral Thesis, Norway, 2004. 